\title{
Cytoprotective Effect of Morinda tinctoria Roxb. against Surgical and Chemical Factor Induced Gastric and Duodenal Ulcers in Rats
}

\author{
D. Sivaraman and P. Muralidharan \\ Department of Pharmacology and Toxicology, C.L. Baid Metha College of Pharmacy, Jyothi Nagar, Thoraipakkam, \\ Chennai 600 097, India \\ Correspondence should be addressed to D. Sivaraman, sivaramand83@gmail.com
}

Received 17 October 2011; Revised 9 November 2011; Accepted 14 November 2011

Academic Editor: T. Arakawa

Copyright ( 2011 D. Sivaraman and P. Muralidharan. This is an open access article distributed under the Creative Commons Attribution License, which permits unrestricted use, distribution, and reproduction in any medium, provided the original work is properly cited.

\begin{abstract}
The present paper relates to the pharmacological validation of the antiulcer efficacy of ethanol leaf extract of Morinda tinctoria Roxb. (EEMT) against aspirin pyloric ligation-induced gastric ulcer model and cysteamine-induced duodenal ulcer in Wistar rats. Oral administration of EEMT at a dose of 200 and $400 \mathrm{mg} / \mathrm{kg}$ significantly prevented the occurrence of aspirin pyloric ligation and cysteamine-induced gastric and duodenal ulceration. The volume and acidity of gastric juice in pyloric ligated rats were significantly $(P<0.01)$ reduced by EEMT. There was a significant decrease in the number of ulcers, and its severity in both the models proved the ulcer protective activity of EEMT. Administration of extract at both dose levels has shown a significant increase in potassium and sodium ion concentration in the gastric juice of pylorus ligation group. On the basis of these observations, we concluded that EEMT possessing antiulcer activity may be due to the modulation of defensive factors by improvement in gastric cytoprotection.
\end{abstract}

\section{Introduction}

In many parts of the world the indigenous systems of medicines are still used effectively and claimed to have cured innumerable diseases which sans complete medical recordings. The origin of this indigenous medicine system dates back before 2000 years. Current modern medicine systems and the standardized principles can be used to test the hypothesis of traditional claims. The use of indigenous medicines is being limited to small tribal and geographical areas as in many parts of Africa and other countries. Peptic ulcer disease (PUD) is one of the oldest diseases known to human kind. The term PUD generally refers to a spectrum of disorders that includes gastric ulcer (GU), pyloric channel ulcer, duodenal ulcer (DU), and postoperative ulcers at or near the site of surgical anastomosis [1].

Long-term use of NSAIDs (nonsteroidal anti-inflammatory drugs) is the second most common cause of ulcers, and the rate of NSAID-caused ulcers is increasing. About 20 million people take prescription NSAIDs regularly, and more than 25 billion tablets of over-the-counter brands are sold each year in the US alone. The most common NSAIDs are aspirin, ibuprofen, and naproxen [2].

Morinda tinctoria Roxb. that belongs to the family Rubiaceae grows wild and is distributed throughout Southeast Asia, commercially known as Nunaa, it is indigenous to tropical countries and is considered as an important folklore medicine. The tribes of Australia used the ripe fruits of MTR for the treatment of respiratory infections [3]. It has been reported to have a broad range of therapeutic and nutritional values [4]. There is a greater demand for its fruit juice in treatment for different kinds of illnesses such as diabetes, arthritis, cancer, gastric ulcer, and other heart disease [5]. The major components have been identified in the Nunaa plant which includes octoanicacid, potassium, vitamin C, terpenoids, scopoletin, flavones, glycosides, linoleicacid, anthraquinones, morindone, rubiadin, and alizarin. [6-9].

Thus, the present study pertains to the evaluation of antiulcer efficacy of ethanol leaf extract of Morinda tinctoria (EEMT) against aspirin pyloric ligation-induced gastric ulcer model and cysteamine-induced duodenal ulcer in Wistar rats. 


\section{Materials and Methods}

2.1. Plant Material. The leaves of Morinda tinctoria were collected from Chenglepet, Tamil nadu, India. The plant material was identified and authenticated by Dr. Sasikala Ethirajulu, research officer (pharmacognosy) of Central Research for Siddha, Government of India, Arumbakkam, Chennai, Tamil nadu, India.

2.2. Preparation of Extract of EEMT. Freshly collected leaves of Morinda tinctoria were dried in shade and pulverized to get a coarse powder. A weighed quantity of the powder (1000 g) was passed through sieve number 40 and subjected to hot solvent extraction in a soxhlet apparatus using ethanol at a temperature range of $60-80^{\circ} \mathrm{C}$, respectively. Before and after every extraction the powder bed was completely dried and weighed. The filtrate was evaporated to dryness at $40^{\circ} \mathrm{C}$ under reduced pressure in a rotary vacuum evaporator. A brownish black waxy residue was obtained. The percentage yield of ethanolic extract was $20.14 \% \mathrm{w} / \mathrm{w}$.

2.3. Phytochemical Screening. Phytochemical screening of the EEMT extract was performed using the reagents and chemicals as follows.

(i) Alkaloids with Mayer's, Hager's, and Dragendorff's reagent.

(ii) Flavonoids with the use of sodium acetate, ferric chloride, and amyl alcohol.

(iii) Phenolic compounds and tannins with lead acetate and gelatin.

(iv) Carbohydrate with Molish's, Fehling's, and Benedict's reagent [10].

(v) Proteins and amino acids with Millon's, and Biuret Xanthoprotein test.

(vi) Saponins test using the hemolysis method.

(vii) Sterols with $5 \%$ potassium hydroxide.

(viii) Steroids with Libermann Burchard's test.

(ix) Saponins with foam and lead acetate test.

(x) Terpenes with thionyl chloride.

(xi) Glycosides with ferric chloride, acetic acid, and concentrated sulphuric acid.

(xii) Gum tested using Molish's reagent and ruthenium red.

(xiii) Coumarin by $10 \%$ sodium hydroxide and quinones by concentrated sulphuric acid.

These were identified by characteristic color changes using standard procedures [11].

The screening results were as follows: alkaloids +; carbohydrates +; proteins and amino acids +; steroids -; sterols +; phenols +, flavonoids +; gums and mucilage +; glycosides + ; saponins -; terpenes + , and tannins -ve.

Where + and - indicates the presence and absence of compounds.
2.4. Acute Toxicity Study [12]. This was performed for the extracts to ascertain safe dose by the acute oral toxic class method by the Organization of Economic Cooperation and Development (OECD). A single administration of starting dose of $2000 \mathrm{mg} / \mathrm{kg}$ body weight/p.o. of the EEMT was administered to three female rats, and the rats were observed for three days to evaluate considerable changes in body weight and other signs of toxicity. There was no considerable change in body weight before and after treatment and no sign of toxicity was observed. When the experiment was repeated again with same dose level, $2000 \mathrm{mg} / \mathrm{kg}$ body weight/p.o. of plant extract for 7 more days and observed for fourteen days no change was observed from the experiments.

2.5. Experimental Animals. Colony inbred strains of Wistar rats weighing 250-300 g, obtained from C. L. Baid Metha College of Pharmacy were used for the pharmacological studies. The animals were kept under standard conditions maintained at $23-25^{\circ} \mathrm{C}, 12 \mathrm{hr}$ light/dark cycle, and given water and standard pellet diet (Hindustan lever, Bangalore) provided ad libitum. The animals were acclimatized to the laboratory conditions for a week prior to the experimentation and randomly divided into four groups of ten animals each. Principles of animal handling were strictly adhered to and the handling of animals was made under the supervision of animal ethics committee of the institute. The experimental protocol was approved by Institutional animal ethics committee (IAEC) of CPCSEA (Committee for the Purpose of Control and Supervision of Experiments on Animals).

2.6. Aspirin-Induced Ulcerogenesis in Pylorus Ligated Rats [13]. Wistar rats of either sex weighing 180 to $250 \mathrm{~g}$ were divided into five groups of six animals each. Animals were placed in cages with grating floor to avoid coprophagy in fasting period.

Group I: Vehicle control. The animals received 1\% CMC (carboxy methyl cellulose) served as control. + PL (pylorus ligated).

Group II: The animals received aspirin $(200 \mathrm{mg} / \mathrm{kg}$ body wt./p.o. only from day 8-10) + PL.

Group III: The animals received aspirin $(200 \mathrm{mg} / \mathrm{kg}$ body wt./p.o.) and EEMT suspended in water at a dose of (200 mg/kg body wt./p.o.) + PL.

Group IV: The animals received aspirin $(200 \mathrm{mg} / \mathrm{kg}$ body wt./p.o.) EEMT suspended in water at a dose of $(400 \mathrm{mg} / \mathrm{kg}$ body wt./p.o.) + PL.

Group V: The animals received aspirin $(200 \mathrm{mg} / \mathrm{kg}$ body wt./p.o.) and ranitidine (50 mg/kg body wt./p.o.) + PL.

Groups III, IV, and V received the assigned drug treatment for the respective 1-10 days daily. From days 8 to 10 (3 days), animals of groups II, III, IV, and V received aspirin 
orally as an aqueous suspension at the dose of $200 \mathrm{mg} / \mathrm{kg}$., $2 \mathrm{~h}$ after the administration of the drugs. Animals in all groups were fasted for $18 \mathrm{~h}$ after the assigned treatment, anaesthetized, and the pylorus was ligated. The rats were sacrificed after $4 \mathrm{~h}$ by excess anesthesia (ether). The stomach was cut open along the greater curvature and the contents drained into small beaker, centrifuged, and then subjected to analysis for following acid secretory and biochemical parameter. The mucosa was flushed with saline and the stomach was pinned on frog board and the ulcer score was calculated [14].

\subsection{Biochemical Estimations}

2.7.1. Determination of Gastric Volume [15]. After sacrificing the rat, the stomach portion was removed. The gastric contents were transferred in to centrifuge tube and centrifuged at $1000 \mathrm{rpm}$ for 10 minutes. The supernatant liquid was then transferred to a measuring cylinder, and the volume was measured.

2.7.2. Determination of $p H$ of Gastric Content [16]. $1 \mathrm{~mL}$ of the gastric juice was collected, and $\mathrm{pH}$ was directly measured by using $\mathrm{pH}$ meter.

2.7.3. Determination of Free Acidity and Total Acidity [17, 18]. $1 \mathrm{~mL}$ of gastric juice was pipette out into a $100 \mathrm{~mL}$ conical flask. 2 to 3 drops of Topfer's reagent were added and titrated with $0.01 \mathrm{~N} \mathrm{NaOH}$ (which was previously standardized with $0.01 \mathrm{~N}$ of oxalic acid) until all the trace of the red color disappeared and the color of the solution was yellowish orange. The volume of the alkali added was noted. This volume corresponds to free acidity. Then 2 to 3 drops of phenolphthalein solution were added and titration was continued until a definite red tinge reappears. Again the total volume of alkali was noted. This volume corresponds to total acidity. Acidity was calculated by using the formula:

$$
\begin{aligned}
\text { Acidity }= & \left(\frac{\text { Vol. of } \mathrm{NaOH} \times \text { Actual normality of } \mathrm{NaOH}}{0.1}\right. \\
& \times 100) \mathrm{mEq} / \mathrm{L} / 100 \mathrm{~g} .
\end{aligned}
$$

\subsubsection{Estimation of Total Proteins [19]}

Reagents: (i) Alkaline copper reagent. Solution A: 2\% sodium carbonate in $0.1 \mathrm{~N}$ sodium hydroxide. Solution B: $0.5 \%$ copper sulphate in $1 \%$ sodium potassium tartrate. $50 \mathrm{~mL}$ of solution A was mixed with $1 \mathrm{~mL}$ of solution B just before use. (ii) Folin's phenol reagent. One volume of Folin's reagent was diluted with two volumes of distilled water just before use. (iii) Standard bovine serum albumin. $20 \mathrm{mg}$ of bovine serum albumin was dissolved in $100 \mathrm{~mL}$ of distilled water. Few drops of $\mathrm{NaOH}$ was added to aid complete dissolution of bovine serum albumin and to avoid frothing, it was allowed to stand overnight in a refrigerator.

The dissolved proteins in gastric juice were estimated in the alcoholic precipitate obtained by adding $90 \%$ of alcohol with gastric juice in 9:1 ratio respectively. Then $0.1 \mathrm{~mL}$ of alcoholic precipitate of gastric juice was dissolved in $1 \mathrm{~mL}$ of $0.1 \mathrm{~N} \mathrm{NaOH}$ and from this $0.05 \mathrm{~mL}$ was taken in another test tube. To this $4 \mathrm{~mL}$ of alkaline copper reagent was added and kept for 10 minutes. Then $0.5 \mathrm{~mL}$ of Folin's phenol reagent was added and again 10 minutes was allowed for color development. Reading was taken against blank prepared with distilled water at $640 \mathrm{~nm}$. The protein content was calculated from standard curve prepared with bovine albumin and has been expressed in terms of $\mu \mathrm{g} / \mathrm{mL}$ of gastric juice.

2.7.5. Estimation of Sodium Ion Concentration in Gastric Juice [20]. Sodium stock solution was prepared by dissolving $0.584 \mathrm{~g} \mathrm{NaCl}$ (equivalent to $0.23 \mathrm{gm}$ of sodium) in $100 \mathrm{~mL}$ of distilled water. $1,2,3,4$, and $5 \mathrm{~mL}$ were pipette out in 5 different $100 \mathrm{~mL}$ volumetric flask, and volume is made up to $100 \mathrm{~mL}$. This solution will contain $2.3,6.9,8.2$, and $11.5 \mathrm{mg}$ of sodium in $100 \mathrm{~mL}$ or $1,2,3,4$, and 5 millimoles (ppm) of sodium, respectively. Appropriate filter is chosen and the flame intensity is adjusted to 100 units by spraying the highest concentration of the stock solution. The concentration of sodium present in the gastric juice was determined by using a Systronics Mediflame 127. The flame intensity of the gastric juice was noted. The concentration of sodium was calculated from the graph. A standard curve was plotted taking conc. in $x$-axis and flame intensity in $y$-axis. The results are expressed in terms of $\mathrm{mg} / \mathrm{L}$.

\subsubsection{Estimation of Potassium Ion Concentration in Gastric} Juice [21]. Potassium stock solution was prepared by dissolving $0.74 \mathrm{~g} \mathrm{KCl}$ (equivalent to $0.39 \mathrm{gm}$ of potassium chloride) dissolved in $100 \mathrm{~mL}$ of distilled water. $0.5,1,2,3,4$, and $5 \mathrm{~mL}$ were pipette out in 6 different $100 \mathrm{~mL}$ volumetric flask, and volume is made up to $100 \mathrm{~mL}$. This solution will contain $1.95 \mathrm{mg}, 3.9 \mathrm{mg}, 5.85 \mathrm{mg}, 7.8 \mathrm{mg}$, and $9.75 \mathrm{mg}$ of potassium in $100 \mathrm{~mL}$ or $0.5,1,1.5,2$, and 2.5 millimoles of potassium respectively. The concentration of potassium present in the gastric juice was determined by using a Systronics Mediflame 127. The flame intensity corresponding to the concentration of stock solution was noted by using appropriate filters. The results were plotted in a graph. The flame intensity of the gastric juice was noted. The concentration of potassium ions was calculated from the graph. The results are expressed in terms of $\mathrm{mg} / \mathrm{L}$.

2.8. Cysteamine-Induced Ulcers [22]. Wistar rats of either sex weighing 180 to $250 \mathrm{~g}$ were divided into five groups of six animals each. Animal were placed in cages with grating floor to avoid coprophagy in fasting period.

Group I: The animals received water and served as control.

Group II: The animals received cysteamine $\mathrm{HCl}$ dissolved in normal saline $(30 \mathrm{mg} / \mathrm{kg}$ body weight $/ \mathrm{s.c})$. The animals received cysteamine $\mathrm{HCl}$ dissolved in normal saline $(30 \mathrm{mg} /$ kg body weight/s.c). 
Group III: The animals received EEMT suspended in water $(200 \mathrm{mg} / \mathrm{kg}$ body weight./p.o.) + cysteamine $\mathrm{HCl}(30 \mathrm{mg} / \mathrm{kg}$ body weight/s.c).

Group IV: The animals received EEMT suspended in water $(400 \mathrm{mg} / \mathrm{kg}$ body weight./p.o.) + cysteamine $\mathrm{HCl}(30 \mathrm{mg} / \mathrm{kg}$ body weight/s.c).

Group V: The animals received pantoprazole in normal saline $(10 \mathrm{mg} / \mathrm{kg}$ body weight./p.o.) + cysteamine $\mathrm{HCl}(30 \mathrm{mg} /$ $\mathrm{kg}$ body weight/s.c).

Groups III, IV, and V received the assigned drug treatment for the respective 5 days daily. On the 5 th day of drug treatment the animals were kept on fast from 10:00 h after the administration of morning dose and last dose of the test drug was then administered at $15: 00 \mathrm{~h}, 1 \mathrm{~h}$ prior to administration of Cysteamine $\mathrm{HCl}(30 \mathrm{mg} / \mathrm{kg}$ body weight/s.c.). The fasting was then continued overnight and the animals were sacrificed at 10:00 $\mathrm{h}$ on the following day, and the duodenum was exposed and scored for the presence or absence of ulcers on the anterior and posterior wall of the duodenum near the pyloric end.

2.9. Histological Examination. Stomach and duodenum obtained from pharmacological studies were immersed in $10 \%$ formalin for $24 \mathrm{~h}$ for histopathological examination. After standard processing, the cut tissue was embedded in paraffin (Automatic Tissue processor, Lipshaw) and cut into $5 \mu \mathrm{m}$ thick sections in a rotary microtome (Lipshaw). The sections were stained with haematoxylin-eosin (Merck) and mounted with Canada balsam. Histological measurement and photographs were taken with a Carl Zeiss Jena ampulla type photomicroscope (magnification 100x).

2.10. Statistical Analysis. The data represents mean \pm SEM. Results were analyzed statistically using one-way ANOVA followed by Dunnett's test. The minimum level of significance was set at $P<0.05$.

\section{Results}

3.1. Effect of EEMT on Gastric Volume in Aspirin + Pylorus Ligated Gastric Ulcer. The gastric volume was significantly increased $(P<0.01)$ in group II animals, when compared to control group I. Administration of EEMT and ranitidine showed a significant $(P<0.01)$ decrease in gastric volume level, when compared to group II animals. Results are shown in Table 1.

\subsection{Effect of EEMT on $\mathrm{pH}$ in Aspirin + Pylorus Ligated Gastric} Ulcer. The $\mathrm{pH}$ level was significantly decreased $(P<0.01)$ in group II animals, when compared to control group I. Administration of EEMT and ranitidine showed a significant $(P<0.01)$ increase in $\mathrm{pH}$ level, when compared to group II animals. Results are shown in Table 2.
TABLE 1: Effect EEMT on gastric volume in aspirin + pylorus ligated gastric ulcer.

\begin{tabular}{lcc}
\hline Group & Treatment & $\begin{array}{c}\text { Gastric volume } \\
(\mathrm{mL} / 100 \mathrm{gm})\end{array}$ \\
\hline I & Control $(0.5 \% \mathrm{SCMC})+\mathrm{PL}$ & $4.80 \pm 0.1014$ \\
II & Aspirin $(200 \mathrm{mg} / \mathrm{kg})+\mathrm{PL}$ & $6.18 \pm 0.1014^{\mathrm{a} * *}$ \\
III & Suspension of EEMT $(200 \mathrm{mg} / \mathrm{kg})+\mathrm{PL}$ & $3.85 \pm 0.1174^{\mathrm{b} * *}$ \\
IV & Suspension of EEMT $(400 \mathrm{mg} / \mathrm{kg})+\mathrm{PL}$ & $3.70 \pm 0.1160^{\mathrm{b} * *}$ \\
V & Standard-ranitidine $(50 \mathrm{mg} / \mathrm{kg})+\mathrm{PL}$ & $3.53 \pm 0.0922^{\mathrm{b} * *}$ \\
\hline
\end{tabular}

The values are expressed as mean \pm SEM of 6 animals.

Comparisons were made between ${ }^{\mathrm{a}}$ group I with group II and ${ }^{\mathrm{b}}$ group II with III, IV, and V.

Statistical significant test for comparison was done by ANOVA, followed by Dunnett's $t$-test, $n=6$ rats. ${ }^{* *} P<0.01$.

TABle 2: Effect EEMT on $\mathrm{pH}$ in aspirin + pylorus ligated gastric ulcer.

\begin{tabular}{lcc}
\hline Group & Treatment & $\mathrm{pH}$ \\
\hline I & Control $(0.5 \% \mathrm{SCMC})+\mathrm{PL}$ & $2.50 \pm 0.1167$ \\
II & Asprin $(200 \mathrm{mg} / \mathrm{kg})+\mathrm{PL}$ & $1.06 \pm 0.1022^{\mathrm{a} * *}$ \\
III & Suspension of EEMT $(200 \mathrm{mg} / \mathrm{kg})+\mathrm{PL}$ & $2.68 \pm 0.1453^{\mathrm{b} * *}$ \\
IV & Suspension of EEMT $(400 \mathrm{mg} / \mathrm{kg})+\mathrm{PL}$ & $3.00 \pm 0.1350^{\mathrm{b} * *}$ \\
V & Standard-ranitidine $(50 \mathrm{mg} / \mathrm{kg})+\mathrm{PL}$ & $3.18 \pm 0.1668^{\mathrm{b} * *}$ \\
\hline
\end{tabular}

The values are expressed as mean \pm SEM of 6 animals.

Comparisons were made between ${ }^{\mathrm{a}}$ group I with group II and ${ }^{\mathrm{b}}$ group II with III, IV, and V.

Statistical significant test for comparison was done by ANOVA, followed by Dunnett's $t$-test, $n=6$ rats. ${ }^{* *} P<0.01$.

TABle 3: Effect EEMT on ulcer score in aspirin + pylorus ligated gastric ulcer.

\begin{tabular}{lcc}
\hline Group & Treatment & Ulcer score \\
\hline I & Control $(0.5 \% \mathrm{SCMC})+\mathrm{PL}$ & $1.70 \pm 0.2236$ \\
II & Asprin $(200 \mathrm{mg} / \mathrm{kg})+\mathrm{PL}$ & $2.56 \pm 0.2108^{\mathrm{a} *}$ \\
III & Suspension of EEMT $(200 \mathrm{mg} / \mathrm{kg})+\mathrm{PL}$ & $1.33 \pm 0.1667^{\mathrm{b} * *}$ \\
IV & Suspension of EEMT $(400 \mathrm{mg} / \mathrm{kg})+\mathrm{PL}$ & $0.96 \pm 0.1557^{\mathrm{b} * *}$ \\
V & Standard-ranitidine $(50 \mathrm{mg} / \mathrm{kg})+\mathrm{PL}$ & $0.66 \pm 0.2108^{\mathrm{b} * *}$ \\
\hline
\end{tabular}

The values are expressed as mean \pm SEM of 6 animals.

Comparisons were made between a group I with group II and ${ }^{\mathrm{b}}$ group II with III, IV, and V.

Statistical significant test for comparison was done by ANOVA, followed by Dunnett's $t$-test, $n=6$ rats. ${ }^{* *} P<0.01$. ${ }^{*} P<0.05$

3.3. Effect of EEMT on Ulcer Score in Aspirin + Pylorus Ligated Gastric Ulcer. The ulcer score was significantly increased $(P<0.01)$ in group II animals, when compared to control group I. Administration of EEMT and ranitidine showed a significant $(P<0.01)$ decrease in ulcer score, when compared to group II animals. Results are shown in Table 3.

3.4. Effect of EEMT on Ulcer Severity in Aspirin + Pylorus Ligated Gastric Ulcer. The ulcer severity was significantly increased $(P<0.01)$ in group II animals, when compared to control group I. Administration of EEMT and ranitidine showed a significant $(P<0.01)$ decrease in ulcer severity, 
TABLE 4: Effect EEMT on ulcer severity in aspirin + pylorus ligated gastric ulcer.

\begin{tabular}{lcc}
\hline Group & Treatment & Ulcer severity \\
\hline I & Control $(0.5 \% \mathrm{SCMC})+\mathrm{PL}$ & $2.10 \pm 0.2473$ \\
II & Asprin $(200 \mathrm{mg} / \mathrm{kg})+\mathrm{PL}$ & $5.40 \pm 0.6680^{\mathrm{a} * *}$ \\
III & Suspension of EEMT $(200 \mathrm{mg} / \mathrm{kg})+\mathrm{PL}$ & $1.64 \pm 0.1567^{\mathrm{b} * *}$ \\
IV & Suspension of EEMT $(400 \mathrm{mg} / \mathrm{kg})+\mathrm{PL}$ & $1.42 \pm 0.1467^{\mathrm{b} * *}$ \\
V & Standard-ranitidine $(50 \mathrm{mg} / \mathrm{kg})+\mathrm{PL}$ & $0.92 \pm 0.3073^{\mathrm{b} * *}$ \\
\hline
\end{tabular}

The values are expressed as mean \pm SEM of 6 animals.

Comparisons were made between ${ }^{\mathrm{a}}$ group I with group II and ${ }^{\mathrm{b}}$ group II with III, IV and V.

Statistical significant test for comparison was done by ANOVA, followed by Dunnett's $t$-test, $n=6$ rats. ${ }^{* *} P<0.01$.

TABLE 5: Effect EEMT on free acidity in aspirin + pylorus ligated gastric ulcer.

\begin{tabular}{lcc}
\hline Group & Treatment & $\begin{array}{c}\text { Free acidity } \\
(\mathrm{mEq} / \mathrm{l} / 100 \mathrm{~g})\end{array}$ \\
\hline I & Control $(0.5 \% \mathrm{SCMC})+\mathrm{PL}$ & $166.25 \pm 0.2424$ \\
II & Asprin $(200 \mathrm{mg} / \mathrm{kg})+\mathrm{PL}$ & $190.20 \pm 0.2764^{\mathrm{a} * *}$ \\
III & $\begin{array}{c}\text { Suspension of EEMT } \\
(200 \mathrm{mg} / \mathrm{kg})+\mathrm{PL}\end{array}$ & $148.16 \pm 0.2186^{\mathrm{b} * *}$ \\
& $\begin{array}{c}\text { Suspension of EEMT } \\
\text { IV }\end{array}$ & $136.06 \pm 0.2216^{\mathrm{b} * *}$ \\
& $\begin{array}{c}\text { Standard-ranitidine } \\
\text { V }\end{array}$ & $130.61 \pm 0.2820^{\mathrm{b} * *}$ \\
\hline
\end{tabular}

The values are expressed as mean \pm SEM of 6 animals.

Comparisons were made between ${ }^{\mathrm{a}}$ group I with group II and ${ }^{\mathrm{b}}$ group II with III, IV, and V.

Statistical significant test for comparison was done by ANOVA, followed by Dunnett's $t$-test, $n=6$ rats. ${ }^{* *} P<0.01$.

when compared to group II animals. Results are shown in Table 4 .

3.5. Effect of EEMT on Free Acidity in Aspirin + Pylorus Ligated Gastric Ulcer. The free acidity $(\mathrm{mEq} / \mathrm{l} / 100 \mathrm{~g})$ was significantly increased $(P<0.01)$ in group II animals, when compared to control group I. Administration of EEMT and ranitidine showed a significant $(P<0.01)$ decrease in free acidity, when compared to group II animals. Results are shown in Table 5.

3.6. Effect of EEMT on Total Acidity in Aspirin + Pylorus Ligated Gastric Ulcer. The total acidity (mEq/l/100 g) was significantly increased $(P<0.01)$ in group II animals, when compared to control group I. Administration of EEMT and ranitidine showed a significant $(P<0.01)$ decrease in total acidity, when compared to group II animals. Results are shown in Table 6.

3.7. Effect of EEMT on Total Protein in Aspirin + Pylorus Ligated Gastric Ulcer. The total protein $(\mu \mathrm{g} / \mathrm{mL})$ was significantly increased $(P<0.01)$ in group II animals, when compared to control group I. Administration of EEMT and ranitidine showed a significant $(P<0.01)$ decrease in total
TABLE 6: Effect EEMT on total acidity in aspirin + pylorus ligated gastric ulcer.

\begin{tabular}{lcc}
\hline Group & Treatment & $\begin{array}{c}\text { Total acidity } \\
(\mathrm{mEq} / \mathrm{L} / 100 \mathrm{~g})\end{array}$ \\
\hline I & Control $(0.5 \% \mathrm{SCMC})+\mathrm{PL}$ & $368.33 \pm 2.77$ \\
II & Asprin $(200 \mathrm{mg} / \mathrm{kg})+\mathrm{PL}$ & $388.10 \pm 2.501^{\mathrm{a} * *}$ \\
III & $\begin{array}{c}\text { Suspension of EEMT } \\
(200 \mathrm{mg} / \mathrm{kg})+\mathrm{PL}\end{array}$ & $336.52 \pm 2.172^{\mathrm{b} * *}$ \\
& $\begin{array}{c}\text { Suspension of EEMT } \\
\text { IV }\end{array}$ & $310.12 \pm 2.012^{\mathrm{b} * *}$ \\
& $\quad(400 \mathrm{mg} / \mathrm{kg})+\mathrm{PL}$ & \\
V & $\begin{array}{c}\text { Standard-ranitidine } \\
(50 \mathrm{mg} / \mathrm{kg})+\mathrm{PL}\end{array}$ & $296.86 \pm 3.169^{\mathrm{b} * *}$ \\
\hline
\end{tabular}

The values are expressed as mean \pm SEM of 6 animals.

Comparisons were made between ${ }^{\mathrm{a}}$ group I with group II and ${ }^{\mathrm{b}}$ group II with III, IV, and V.

Statistical significant test for comparison was done by ANOVA, followed by Dunnett's $t$-test, $n=6$ rats. ${ }^{* *} P<0.01$.

TABLE 7: Effect EEMT on total protein in aspirin + pylorus ligated gastric ulcer.

\begin{tabular}{lcc}
\hline Group & Treatment & Total protein $(\mu \mathrm{g} / \mathrm{mL})$ \\
\hline I & Control $(0.5 \% \mathrm{SCMC})+\mathrm{PL}$ & $559.19 \pm 4.2202$ \\
II & Asprin $(200 \mathrm{mg} / \mathrm{kg})+\mathrm{PL}$ & $643.33 \pm 5.3004^{\mathrm{a} * *}$ \\
& $\quad$ Suspension of EEMT & $353.21 \pm 6.5614^{\mathrm{b} * *}$ \\
III & $(200 \mathrm{mg} / \mathrm{kg})+$ PL & \\
& $\begin{array}{c}\text { Suspension of EEMT } \\
\text { IV }\end{array}$ & $320.12 \pm 6.2210^{\mathrm{b} * *}$ \\
& $(400 \mathrm{mg} / \mathrm{kg})+$ PL & \\
V & $\begin{array}{c}\text { Standard-ranitidine } \\
(50 \mathrm{mg} / \mathrm{kg})+\mathrm{PL}\end{array}$ & $265.2 \pm 6.2158^{\mathrm{b} * *}$ \\
\hline
\end{tabular}

The values are expressed as mean \pm SEM of 6 animals.

Comparisons were made between ${ }^{\mathrm{a}}$ group I with group II and ${ }^{\mathrm{b}}$ group II with III, IV, and V.

Statistical significant test for comparison was done by ANOVA, followed by Dunnett's $t$-test, $n=6$ rats. ${ }^{* *} P<0.01$.

acidity, when compared to group II animals. Results are shown in Table 7.

3.8. Effect of EEMT on Sodium Ion in Aspirin + Pylorus Ligated Gastric Ulcer. The sodium ion concentration in the gastric juice $(\mathrm{mg} / \mathrm{L})$ was significantly decreased $(P<0.01)$ in group II animals, when compared to control group I. Administration of EEMT and ranitidine showed a significant $(P<0.01)$ increase in sodium ions, when compared to group II animals. Results are shown in Table 8.

3.9. Effect of EEMT on Potassium Ion in Aspirin + Pylorus Ligated Gastric Ulcer. The potassium ion concentration in the gastric juice $(\mathrm{mg} / \mathrm{L})$ was significantly decreased $(P<$ 0.01 ) in group II animals, when compared to control group I. Administration of EEMT and ranitidine showed a significant $(P<0.01)$ increase in potassium ions, when compared to group II animals. Results are shown in Table 9.

3.10. Effect of EEMT on Ulcer Scores in Cysteamine HClInduced Duodenal Ulcer. The ulcer score was significantly increased $(P<0.05)$ in group II animals, when compared to 
TABLE 8: Effect EEMT on sodium ion in aspirin + pylorus ligated gastric ulcer.

\begin{tabular}{lcc}
\hline Group & Treatment & Sodium ion $\mathrm{mg} / \mathrm{L}$ \\
\hline I & Control $(0.5 \% \mathrm{SCMC})+\mathrm{PL}$ & $0.25 \pm 0.03$ \\
II & Asprin $(200 \mathrm{mg} / \mathrm{kg})+\mathrm{PL}$ & $0.18 \pm 0.01^{\mathrm{a} * *}$ \\
III & Suspension of EEMT $(200 \mathrm{mg} / \mathrm{kg})+\mathrm{PL}$ & $0.30 \pm 0.04^{\mathrm{b} * *}$ \\
IV & Suspension of EEMT $(400 \mathrm{mg} / \mathrm{kg})+\mathrm{PL}$ & $0.50 \pm 0.01^{\mathrm{b} * *}$ \\
V & Standard-ranitidine $(50 \mathrm{mg} / \mathrm{kg})+\mathrm{PL}$ & $0.56 \pm 0.02^{\mathrm{b} * *}$ \\
\hline
\end{tabular}

The values are expressed as mean \pm SEM of 6 animals.

Comparisons were made between ${ }^{\mathrm{a}}$ group I with group II and ${ }^{\mathrm{b}}$ group II with III, IV, and V.

Statistical significant test for comparison was done by ANOVA, followed by Dunnett's $t$-test, $n=6$ rats. ${ }^{* *} P<0.01$.

TABLE 9: Effect EEMT on potassium ion in aspirin + pylorus ligated gastric ulcer.

\begin{tabular}{lcc}
\hline Group & Treatment & $\begin{array}{c}\text { Potassium ion } \\
\mathrm{mg} / \mathrm{L}\end{array}$ \\
\hline I & Control $(0.5 \% \mathrm{SCMC})+\mathrm{PL}$ & $0.26 \pm 0.02$ \\
II & Asprin $(200 \mathrm{mg} / \mathrm{kg})+\mathrm{PL}$ & $0.13 \pm 0.03^{\mathrm{a} * *}$ \\
III & Suspension of EEMT $(200 \mathrm{mg} / \mathrm{kg})+\mathrm{PL}$ & $0.30 \pm 0.02^{\mathrm{b} * *}$ \\
IV & Suspension of EEMT $(400 \mathrm{mg} / \mathrm{kg})+\mathrm{PL}$ & $0.35 \pm 0.01^{\mathrm{b} * *}$ \\
$\mathrm{~V}$ & Standard-ranitidine $(50 \mathrm{mg} / \mathrm{kg})+\mathrm{PL}$ & $0.39 \pm 0.03^{\mathrm{b} * *}$ \\
\hline
\end{tabular}

The values are expressed as mean \pm SEM of 6 animals.

Comparisons were made between ${ }^{\mathrm{a}}$ group I with group II and ${ }^{\mathrm{b}}$ group II with III, IV, and V.

Statistical significant test for comparison was done by ANOVA, followed by Dunnett's $t$-test, $n=6$ rats. ${ }^{* *} P<0.01$.

TABLE 10: Effect EEMT on ulcer scores in cysteamine $\mathrm{HCl}$ induced duodenal ulcer.

\begin{tabular}{lcc}
\hline Group & Treatment & Ulcer score DU \\
\hline I & Control (water) & $1.15 \pm 0.25$ \\
II & Cysteamine HCl $(30 \mathrm{mg} / \mathrm{kg})$ in n.s & $3.23 \pm 0.20^{\mathrm{a} *}$ \\
III & $\begin{array}{c}\text { Suspension of EEMT }(200 \mathrm{mg} / \mathrm{kg})+ \\
\text { Cysteamine HCl }(30 \mathrm{mg} / \mathrm{kg})\end{array}$ & $2.62 \pm 0.28^{\mathrm{b} * *}$ \\
IV & Suspension of EEMT $(400 \mathrm{mg} / \mathrm{kg})+$ & $2.05 \pm 0.18^{\mathrm{b} * *}$ \\
& Cysteamine HCl $(30 \mathrm{mg} / \mathrm{kg})$ \\
V & Pantoprazole $(10 \mathrm{mg})+$ cysteamine & $1.68 \pm 0.40^{\mathrm{b} * *}$ \\
\hline
\end{tabular}

The values are expressed as mean \pm SEM of 6 animals.

Comparisons were made between ${ }^{\mathrm{a}}$ group I with group II and ${ }^{\mathrm{b}}$ group II with III, IV, and V.

Statistical significant test for comparison was done by ANOVA, followed by Dunnett's $t$-test, $n=6$ rats. ${ }^{* *} P<0.01,{ }^{*} P<0.05$.

control group I. Administration of EEMT showed a significant $(P<0.01)$ decrease in ulcer score, pantoprazole group showed significant $(P<0.01)$ decrease when compared to group II animals. Results are shown in Table 10.

3.11. Effect of EEMT on Histological Examination. Pylorus ligation and aspirin-treated $(200 \mathrm{mg} / \mathrm{kg})$ rats showed sharply defined mucosal ulcer in stomach. Damaged mucosal epithelium and cellular debris were found in the ulcerated wall of stomach (Figure 1(b)). Ranitidine-treated $(50 \mathrm{mg} / \mathrm{kg}$ ) rats showed clear evidence of restoration of mucosal epithelium and normally arranged glands (Figure 1(e)). EEMT-treated $(200 \mathrm{mg} / \mathrm{kg})$ rats showed little cellular debris with regular architecture of epithelium but mucosal epithelium was not formed completely (Figure 1(c)). EEMT-treated (400 mg/kg) rats showed reduced inflammatory exudates along with good extent of mucosal regeneration (Figure 1(d)). Sign of healing was seen at both dose levels of EEMT-treated groups, similar to control rats (Figure 1(a)).

EEMT at both dose levels was found to preserve the functional cytoarchitecture of the duodenum in the damaged regions (Figures 2(c) and 2(d)). Pantoprazole-treated $(10 \mathrm{mg} / \mathrm{kg})$ rats (Figure $2(\mathrm{e}))$ showed regular alignment of duodenal secretary epithelial cells when compared to Cysteamine-treated group (Figure 2(b)) which has shown irregular pattern of epithelial cells in comparison to control group (Figure 2(a)).

\section{Discussion}

Morinda tinctoria Roxb plant extracts having potent phytochemical components have been screened for various disorders including peptic ulcer disease [23]. Most of the plants with active phytochemical are present in Indian system of medicines used alone or with combination. Treatment of PUD in Ayurveda and Siddha systems of medicine has formulations containing plants and minerals.

Preliminary phytochemical analysis of the EEMI shows rich possession of phytochemical such as alkaloids, carbohydrates, proteins and amino acids, sterols, phenols, flavonoids, gums and mucilage, glycosides, and terpenes which are potent antioxidants and most of them have been reported for antiulcer activity and antibacterial activity [24]. Pylorus ligation-induced ulcers lesions occur because of an increase in acid-pepsin accumulation due to pylorus obstruction, concomitant exposure to asprin causes mucosal digestion [25]. Asprin inhibits gastric mucosal cyclo-oxygenase production of prostacyclins and prostaglandins, known to be the potent vasodilators involved in the local regulation of microcirculation. Inhibition of prostaglandins, in fact, results in the production of areas of generalized ischemia within the gastric mucosa, which is then attacked by pepsin or acid, leading to tissue necrosis and erosion formation [26].

Treatment with EEMT at the dose of 200 and $400 \mathrm{mg} / \mathrm{kg}$ b.w showed significant reduction in volume of gastric juice $(P<0.01)$ compared to control. This suggests its action on vagus-vagal reflex, as pylorus ligature causes gastric hypersecretion due to activation of the vagus-vagal reflex by stimulation of baroreceptors in the antral gastric mucosa which in turn believed to increase gastric tonus and secretion [27].

EEMT at both the dose levels of 200 and $400 \mathrm{mg} / \mathrm{kg}$ b.w showed significant increase in $\mathrm{pH}$ of the gastric juice to near normal $(P<0.01)$ compared to control, and also significant decrease in ulcer score and severity was observed in treatment group when compared with control animals. This suggests the possible cytoprotective action of EEMT with less influence on prostaglandins. Further it was 


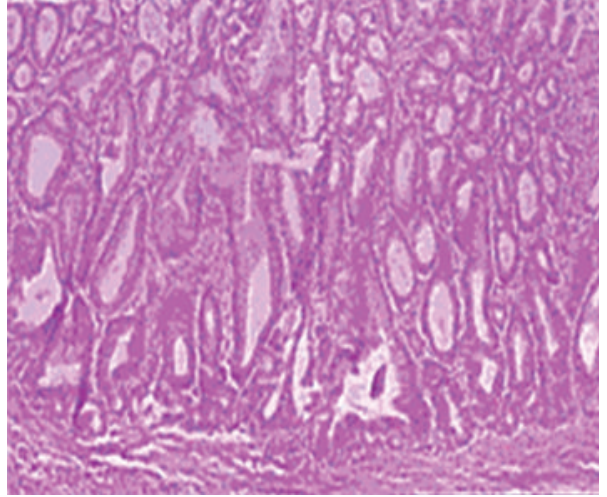

(a) Group I

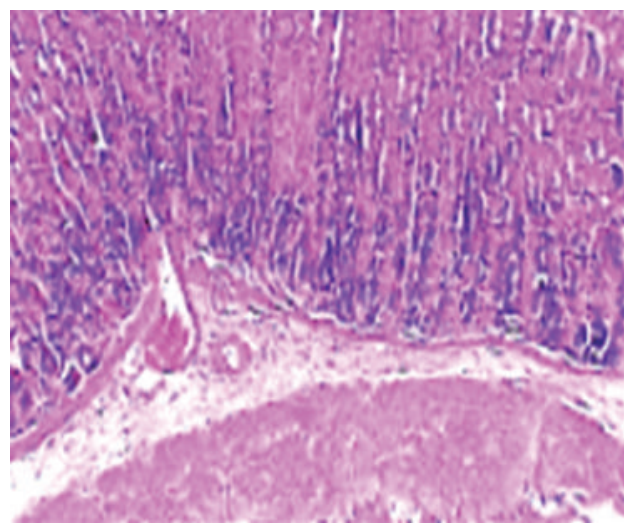

(c) Group III

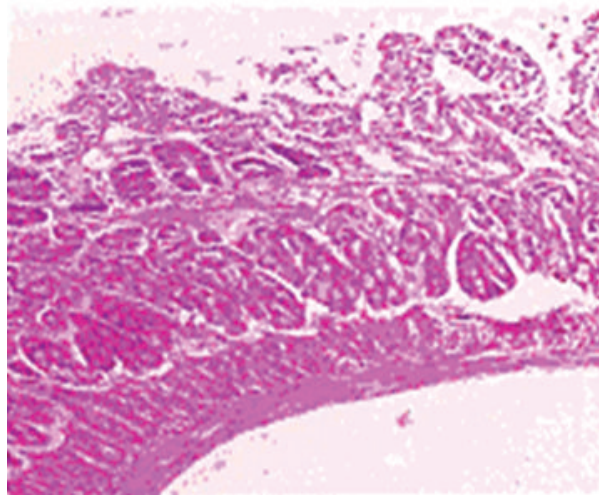

(b) Group II

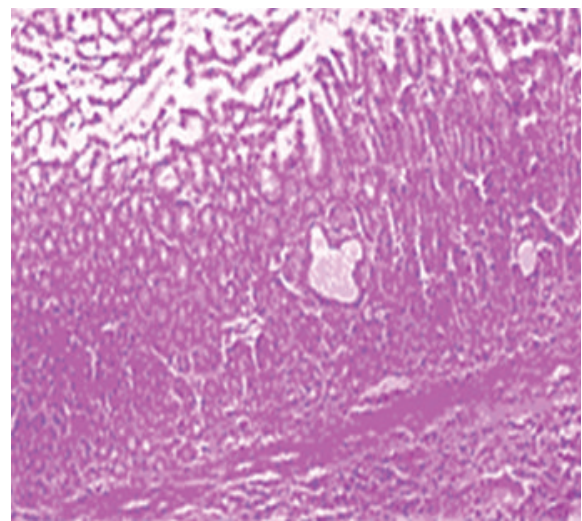

(d) Group IV

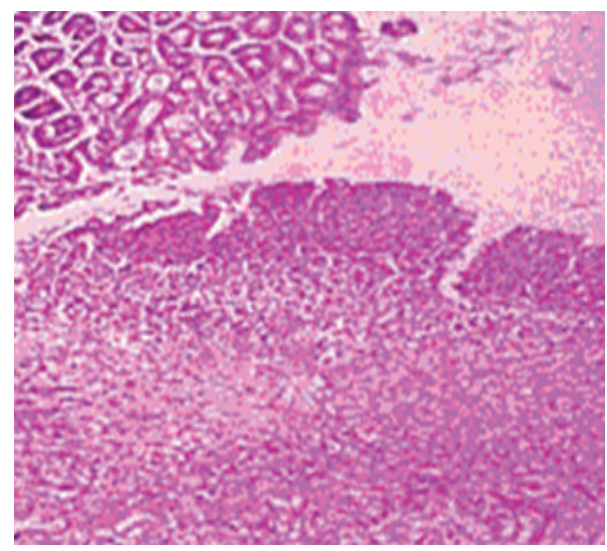

(e) Group V

FIGURE 1: Histopathology of stomach after exposure to aspirin plus pylorus ligation EEMT.

reported that increase in bicarbonate ion concentration plays an important role in protecting the gastric and duodenal mucosa against hydrochloric acid. This property may also explain the significant decrease $(P<0.01)$ in free acidity and total acidity level in EEMT-treated groups.

Administration of EEMT at the dose of 200 and $400 \mathrm{mg} /$ $\mathrm{kg}$ b.w showed significant increase in sodium and potassium ions in gastric juice $(P<0.01)$ compared to control. The increase in the potassium ion in turn reflects in the increase in hydrogen ion concentration and bicarbonate ion concentration. EEMT at both dose levels showed significant reduction in dissolved protein content $(P<0.01)$ compared to control. Decrease in protein content in the gastric juice signifies decrease in leakage from the mucosal cells indicating increased mucosal resistance [28].

EEMT at the dose of $400 \mathrm{mg} / \mathrm{kg}$ b.w showed significant reduction in duodenal ulcer $(P<0.01)$ when compared to control. In histological study, pretreatment with EEMT was found to preserve the functional cytoarchitecture of the gastric mucosa, the treatment showed regeneration of gastric 


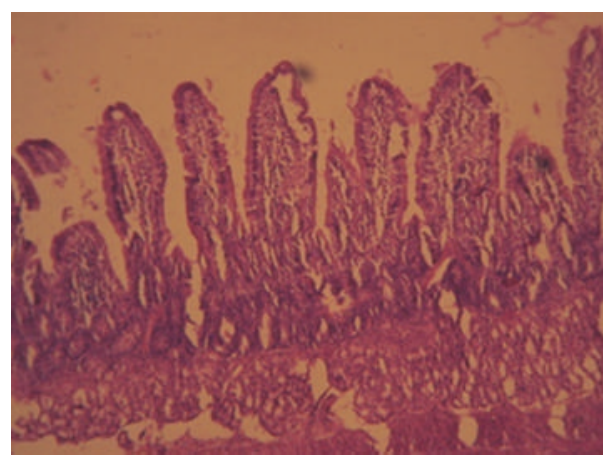

(a) Group I

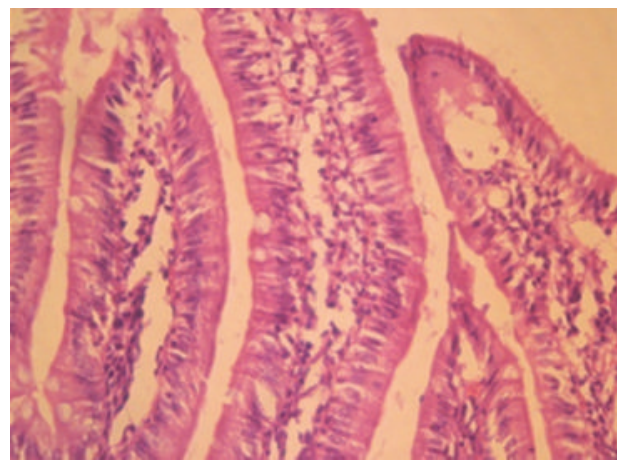

(c) Group III

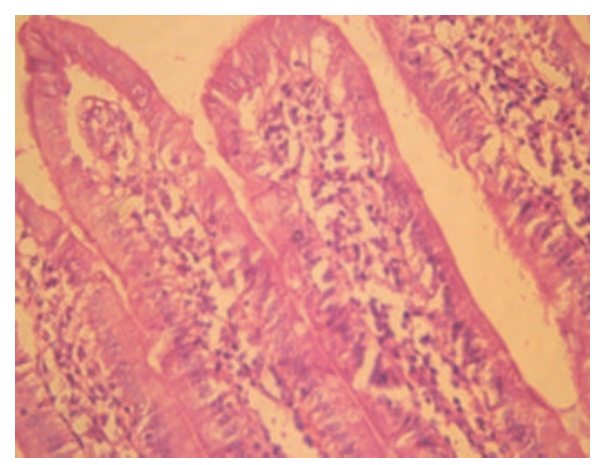

(b) Group II

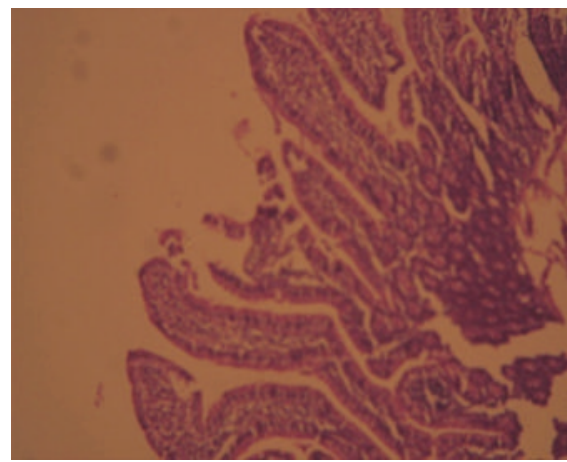

(d) Group IV

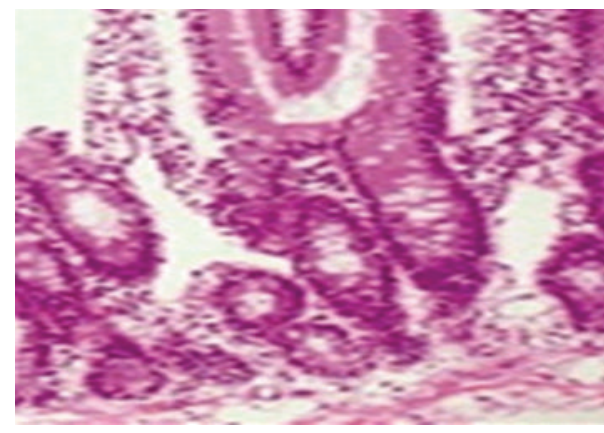

(e) Group V

FIgURE 2: Histopathology of duodenum in Cysteamine-induced duodenal ulcer EEMT.

mucosa in the damaged regions. Pretreatment with EEMT was found to preserve the functional cytoarchitecture of the gastric mucosa it also revealed regeneration of gastric mucosa in the damaged regions.

\section{Conclusion}

Morinda tinctoria leaf extract at both dose levels shows significant decrease in secretions of gastric juice and reduction in number of ulcers. It was observed that severity of ulcer lesion, free acidity, and total acidity was reduced in the EEMT treatment groups. Reduction in the total protein content in the gastric juice was a positive observation which indicates that increased mucosal resistance. It is clearly evident that the evaluated phytoconstituents like flavonoids, alkaloids, and glycosides which are present in EEMT possess anti-ulcer property by inhibition of gastric acid secretion which in turn strengthens the mucosal barrier and reduces ulcers.

\section{Acknowledgments}

The authors are grateful to Dr. S. Venkataraman (director of C.L. Baid Metha Foundation for Pharmaceutical Education and Research, Chennai) for his technical and secretarial assistance. The authors have no conflict of interest to report.

\section{References}

[1] H. M. T. El-Zimaity, "Recent advances in the histopathology of gastritis," Current Diagnostic Pathology, vol. 13, no. 4, pp. 340-348, 2007.

[2] S. Dhikav, S. Sing, and S. Pande, "Non-steroidal drug-induced gastrointestinal toxicity: mechanisms and management," Journal, Indian Academy of Clinical Medicine, vol. 4, no. 4, 2003. 
[3] WHO Expert Committee on Diabetes Mellitus, Technical Reports Series, World Health Organisation, Geneva, Switzerland, 1980.

[4] W. Whistler, Tongan Herbal Medicine, Isle Botanica, Honolulu, Hawaii, USA, 1992.

[5] M. Y. Wang, B. J. West, C. J. Jensen et al., "Morinda citrifolia (Noni): a literature review and recent advances in Noni research," Acta Pharmacologica Sinica, vol. 23, no. 12, pp. 1127-1141, 2002.

[6] O. Levand and H. O. Larson, "Some chemical constituents of Morinda citrifolia," Planta Medica, vol. 36, no. 2, pp. 186-187, 1979.

[7] J. P. Farine, L. Legal, B. Moreteau, and J. L. Le Quere, "Volatile components of ripe fruits of Morinda citrifolia and their effects on Drosophila," Phytochemistry, vol. 41, no. 2, pp. 433$438,1996$.

[8] N. K. Moorthy and G. S. Reddy, "Preliminary phytochemical and pharmacological study of Morinda tinctoria," Linn. Antiseptic, vol. 67, pp. 167-171, 1970.

[9] J. Singh and R. D. Tiwari, "Flavone glycosides from the flowers of Morinda citrofolia," Journal of the Indian Chemical Society, vol. 53, no. 4, article 424, 1976.

[10] J. B. Harbone, Phyto Chemical Methods, Chapman \& Hall, London, UK, 1973.

[11] G. E. Trease and W. C. Evans, "Pharmacognosy," in Phenols and Phenolic Glycosides, pp. 223-249, ELBS, London, UK, 1989.

[12] J. Donald Ecobichon, The Basis of Toxicity Testing, CRC Press, New York, NY, USA, 1997.

[13] J. Jayaraman, Laboratory Manual in Biochemistry, New Age International, New Delhi, India, 1st edition, 1981.

[14] H. Gerhard Vogel, Drug Discovery and Evaluation-Pharmacological Assays, Springer, Heidelberg, Germany, 2002.

[15] E. J. Beckers, N. J. Rehrer, F. Brouns, F. Ten Hoor, and W. H. M. Saris, "Determination of total gastric volume, gastric secretion and residual meal using the double sampling technique of George," Gut, vol. 29, no. 12, pp. 1725-1729, 1988.

[16] A. Hussain and S. S. Habib, "Effect of cimetidine on reduction of gastric secretion and ph in adult patients undergoing elective surgery and its impact on aspiration risk," Pakistan Journal of Physiology, vol. 3, no. 1, pp. 8-13, 2007.

[17] P. Hawk, B. Oser, and W. Summerson, Gastric Analysis. Practical Physiological Chemistry, CRC Press, Toronto, Canada, 1954.

[18] M. Minaiyan, D. N. Ghassemi, and B. Mohammadzadeh, "Anti-ulcer effect of Tripleurospermum disciforme (C.A.Mey) Shultz Bip on pylorus ligated rats," Research in Pharmaceutical Sciences, vol. 1, pp. 15-21, 2006.

[19] O. H. Lowry, N. J. Rosenbrough, A. L. Farr, and R. J. Randall, "Protein measurement with the Folin phenol reagent," The Journal of Biological Chemistry, vol. 193, no. 1, pp. 265-275, 1951.

[20] G. H. Jeffery, J. Bassett, J. Mendham, and R. C. Denney, Vogel's Textbook of Quantitative Chemical Analysis, Longman Scientific and technical publications, London, 5th edition, 1991.

[21] P. Manoharan and S. John, "Anti-ulcer effect of coccinia grandis (linn.) on pylorus ligated (albino) rats," International Journal of Research and Development, vol. 2, no. 5, pp. 1-9, 2010.

[22] K. Sairam, S. Priyambada, N. C. Aryya, and R. K. Goel, "Gastroduodenal ulcer protective activity of Asparagus racemosus: an experimental, biochemical and histological study," Journal of Ethnopharmacology, vol. 86, no. 1, pp. 1-10, 2003.
[23] A. Anoop and M. Jegadeesan, "Biochemical studies on the anti-ulcerogenic potential of Hemidesmus indicus R.Br. var. indicus," Journal of Ethnopharmacology, vol. 84, no. 2-3, pp. 149-156, 2003.

[24] H. S. Falcao, I. R. Mariath, M. F. F. M. Diniz, L. M. Batista, and J. M. Barbosa-Filho, "Plants of American Continent with anti ulcer activity," Phytomedicine, vol. 15, pp. 132-146, 2008.

[25] A. M. E. El-Arab, M. G. Shenoda, M. H. Eman, and B. A. Azzat, "Effect of dietary honey on intestinal microflora and toxicity of mycotoxins in mice," BMC Complementary and Alternative Medicine, vol. 6, article 6, 2006.

[26] R. K. Goel, A. Chakrabarti, and A. K. Sanyal, "The effect of biological variables on the anti-ulcerogenic effect of vegetable plantain banana," Planta Medica, vol. 2, pp. 85-88, 1985.

[27] C. Dixit, R. Leena, and D. Madhu, "Effect of nitric oxide modulators on pylorus-ligation-induced ulcers in the rat," Pharmacological Research, vol. 39, no. 1, pp. 33-39, 1999.

[28] J. A. Rodríguez, L. Astudillo, and G. Schmeda-Hirschmann, "Oleanolic acid promotes healing of acetic acid-induced chronic gastric lesions in rats," Pharmacological Research, vol. 48, no. 3, pp. 291-294, 2003. 


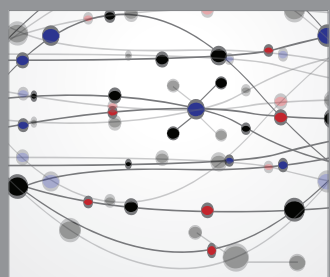

The Scientific World Journal
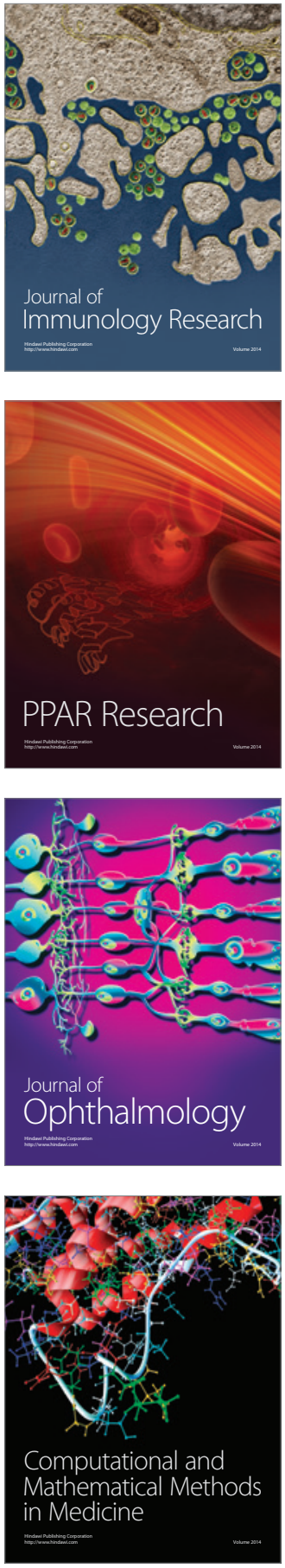

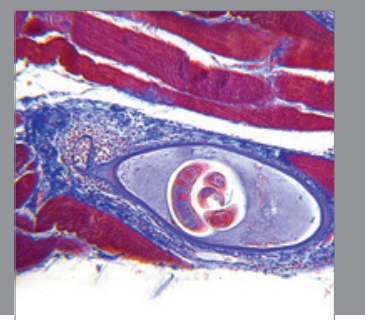

Gastroenterology

Research and Practice
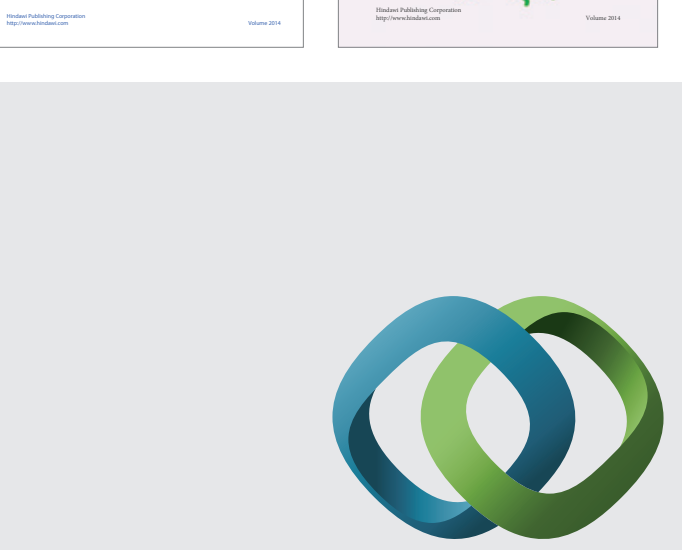

\section{Hindawi}

Submit your manuscripts at

http://www.hindawi.com
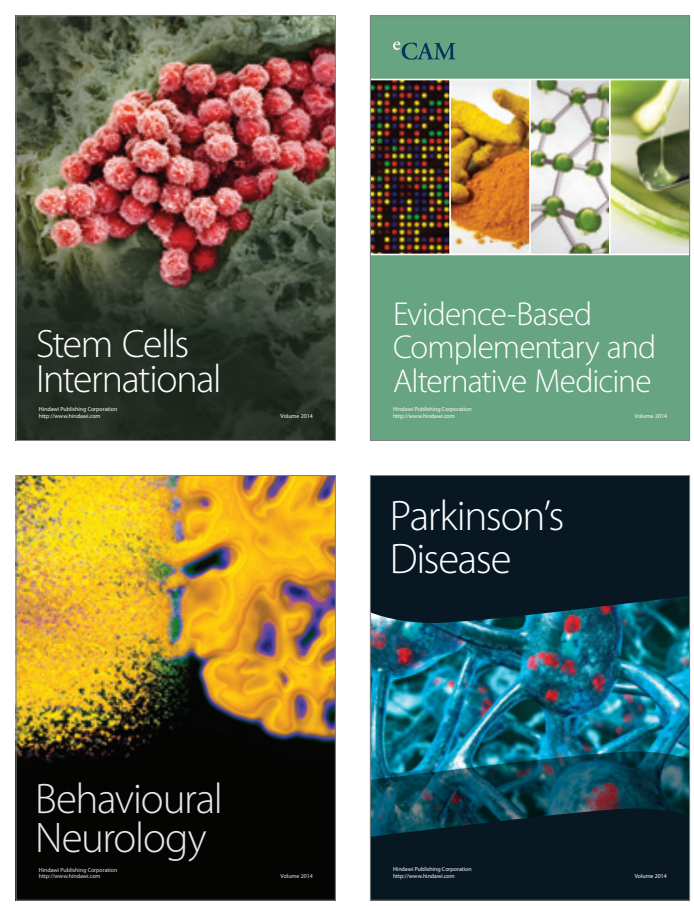

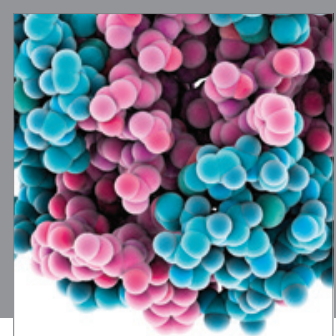

Journal of
Diabetes Research

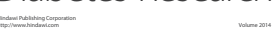

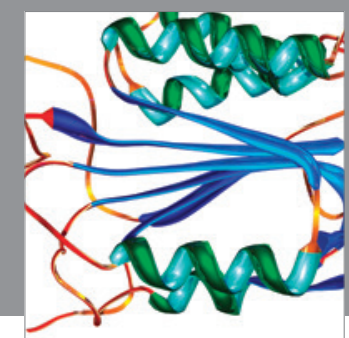

Disease Markers
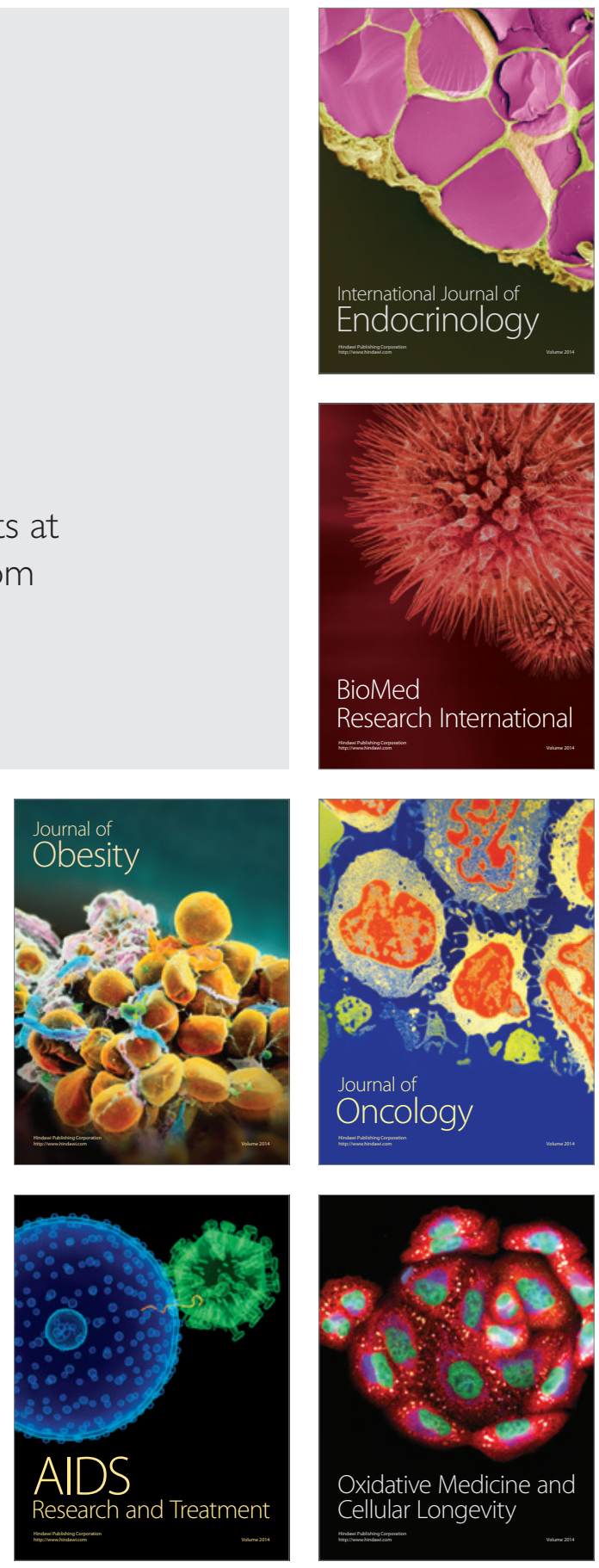